JBB/Vol.2 Issue 2

\title{
Comparative Biological Availability of Clopidogrel Formulation in Healthy Volunteers After a Single Dose Administration
}

\author{
Eduardo Abib Junior ${ }^{1,2 *}$, Luciana Fernandes Duarte ${ }^{2}$, Moisés Luís Pirasol Vanunci², \\ Daniela Aparecida de Oliveira², Tatiane Antonelli Stein ${ }^{2}$, Renata Pereira ${ }^{2}$, \\ Antonio Ricardo Amarante ${ }^{2}$, Eunice Mayumi Suenaga ${ }^{3}$, Alessandro de Carvalho Cruz $^{4}$
}

\author{
'Department of Clinical Medicine, Faculty of Medical Sciences, State University of \\ Campinas (UNICAMP), 13083-970, Campinas, SP, Brazil \\ ${ }^{2}$ Scentryphar Clinical Research, 13020-420, Campinas, SP, Brazil \\ ${ }^{3}$ Nucleus of Bioequivalence and Clinical Research (NUBEC), 04041-152, São Paulo, SP, Brazil \\ ${ }^{4}$ Association for Development of the Medicine (SPDM), 04041-152, São Paulo, SP, Brazil
}

\begin{abstract}
The study was performed to compare the bioavailability of two clopidogrel $75 \mathrm{mg}$ tablet formulation (Clopidogrel from Sandoz as test formulation and Plavix from SanofiSynthelabo Ltda, Brazil, as reference formulation) in 42 volunteers of both sexes. The study was conducted open with randomized two period crossover design and a one week wash out period. Plasma samples were obtained over a 48 hour interval. The carboxylic acid of Clopidogrel, major metabolite of Clopidogrel, was analyzed by LC-MS-MS, in the presence of enalapril maleate as internal standard. With plasma concentration vs. time curves, data obtained from this metabolite, the following pharmacokinetics parameters were obtained: $\mathrm{AUC}_{0-\mathrm{t}}, \mathrm{AUC}_{0 \text {-inf }}$ and $\mathrm{C}_{\text {max }}$. Geometric mean of Clopidogrel/Plavix $75 \mathrm{mg}$ individual percent ratio was $100.33 \% \mathrm{AUC}_{0-\mathrm{t}}, 98.96 \%$ for $\mathrm{AUC}_{0 \text {-inf }}$ and $105.83 \%$ for $\mathrm{C}_{\max }$. The $90 \%$ confidence intervals were 95.50-105.40\%, 94.45-103.69\%, 95.91-116.78\%, respectively. Since the $90 \%$ confidence intervals for $\mathrm{C}_{\max }$, $\mathrm{AUC}_{0-\mathrm{t}}$ and $\mathrm{AUC}_{0 \text {-inf }}$ were within the $80-125 \%$ interval proposed by Food and Drug Administration, it was concluded that Clopidogrel $75 \mathrm{mg}$ Tablet was bioequivalent to Plavix $75 \mathrm{mg}$ tablet according to both the rate and extent of absorption.
\end{abstract}

Keywords: Therapeutic equivalency; Biological availability; Pharmacokinetics; Chromatography; Bioequivalence

\section{Introduction}

Clopidogrel hydrogen sulfate, methyl (+)- $(S)-\alpha-$ (ochlorophenyl)-6, 7-dihydrothieno [3, 2-c] pyridin-5(4H)acetate hydrogensulfate, is a thienopyridine derivative that irreversibly blocks ADP receptor. Clopidogrel is chemically related to ticlopidine with superior side effects profile and dosing requirements. The drug which reduces platelet aggregation is extensively used for prevention of thrombosis in patients undergoing placement of a coronary stent (Majerus and Tollefsen, 2006). The drug is rapidly, but incompletely, absorbed after oral administration and extensively metabolized to an active metabolite. The parent drug and active metabolite are low in plasma. The major circulating compound however, is an inactive carboxylic derivative, which its blood concentration is used to document the pharmacokinetic profile of clopidogrel (Herbert et al., 1993).
Clinical studies have showed that Clopidogrel added to aspirin is beneficial in the treatment of patients with acute ST-elevation MI. Patients with unstable angina or non-ST-elevation MI should be treated with aspirin plus Clopidogrel for at least 9 months to reduce the risk vascular death, nonfatal MI, and nonfatal stroke (Aronow, 2007).

The objective of this study was to compare in healthy volunteers, the pharmacokinetics profiles and evaluate the bioequivalence of one test formulation of $75 \mathrm{mg}$ tablet of Clopidogrel, elaborated by Sandoz do Brasil Indústria Farmacêutica Ltda, Brazil (test formulation). The test formulation was compared to one commercial formulation of $75 \mathrm{mg}$ of Clopidogrel (Plavix) by Sanofi-Synthelabo Ltda, Brazil (reference formulation).

\section{Methods}

\section{Study protocol}

The study was performed in accordance with the Helsinki Declaration and Good Clinical Practice Guideline, and informed consent was obtained from participants prior to study commencement. The clinical part of the study was condueted at Scentryphar Clinical Research (Campinas City, São Paulo, Brazil) and the bioanalytical part at Nucleus of Bioequivalence and Clinical Research/NUBEC (São Paulo, Brazil).

\section{Subjects}

Forty two healthy volunteers of both sexes (21 males and 21 females) who were between the ages of 18 and 43 (mean \pm SEM: $28.7 \pm 7.6$ years), who had heights between $150.0 \mathrm{~cm}$ and 190.0 $\mathrm{cm}(170.0 \pm 1.1 \mathrm{~cm})$, and who weighed between $48.8 \mathrm{~kg}$ and 81.2 $\mathrm{kg}(66.7 \pm 8.1 \mathrm{~kg})$ and within $15 \%$ of their ideal body weight were enrolled in the study. Subjects were judged eligible for

*Corresponding author: Eduardo Abib Junior, Scentryphar Clinical Research, 885, Barão de Itapura ave, Campinas, SP - Brazil- 13020-420; Tel: (19) 3232-6350; Fax: (19) 3231-6715; E-mail: eabib@scentryphar.com

Received March 04, 2010; Accepted April 02, 2010; Published April 02, 2010

Citation: Abib E, Duarte LF, Vanunci MLP, Oliveira de DA, Antonelli S, et al. (2010) Comparative Biological Availability of Clopidogrel Formulation in Healthy Volunteers After a Single Dose Administration. J Bioequiv Availab 2: 045-049. doi:10.4172/jbb. 1000029

Copyright: (C) 2010 Abib E, et al. This is an open-access article distributed under the terms of the Creative Commons Attribution License, which permits unrestricted use, distribution, and reproduction in any medium, provided the original author and source are credited. 
Citation: Abib E, Duarte LF, Vanunci MLP, Oliveira de DA, Antonelli S, et al. (2010) Comparative Biological Availability of Clopidogrel Formulation in Healthy Volunteers After a Single Dose Administration. J Bioequiv Availab 2: 045-049. doi:10.4172/ jbb. 1000029

enrolment in this study if they were in compliance with all the inclusion and exclusion criteria described in the protocol.

All the subjects provided written informed consent to participate after explaining the nature and purpose of the study. The study protocol was approved by the M.M. Assert Serviços Médicos S/A Ltda with the ethical principles described in the Declaration of Helsinki, guidelines for International Conference on Harmonization-Good clinical practices (ICH-GCP).

All volunteers were healthy as assessed by physical examination, ECG, and the following laboratory tests: blood glucose, urea, creatinine, AST, ALT, alkaline phosphatase, Gamma GT, total bilirrubin, albumin and total protein, triglycerides, total cholesterol, hemoglobin, hematocrit, total and differential white cell counts and routine urine. All subjects were negative for HIV, HBV (except for serological scare) and HCV.

\section{Drug products}

The test formulation employed was Clopidogrel $75 \mathrm{mg}$ tablet (lot number KW04I04N) and the reference formulation was: Plavix $75 \mathrm{mg}$ tablet (lot number 5063596).

\section{Study Design}

The study was performed to compare the bioavailability of two Clopidogrel $75 \mathrm{mg}$ tablet formulation (Clopidogrel from Sandoz as test formulation and Plavix from Sanofi-Synthelabo Ltda, Brazil, as reference formulation) under fasting conditions. Formulation was tested for bioequivalence for the first time.

The study was conducted in an open randomized 2 period crossover balanced design with a 1 week wash out period between the doses. During each period, the volunteers were hospitalized at 8:00 pm having already had a normal evening meal, and after an overnight fast they received at 7:00 am a single $75 \mathrm{mg}$ tablet Clopidogrel dose of either formulation. Water $(200 \mathrm{~mL})$ was given immediately after drug administration. All volunteers were then fasted 05 hours following the drug administration, after which a standard lunch was consumed and an evening meal was provided 10 hours after dosing. No other food was permitted during the "in-house" period. Liquid consumption was permitted ad libitum after lunch but xanthine-containing drinks including tea, coffee and cola were avoided. Systolic and Diastolic arterial pressure (measured on invasively with a sphygmomanometer automatic by Omron equipment), heart rate and temperature were recorded just before and hourly after drug administration.

Blood samples $(06 \mathrm{~mL})$ from a suitable antecubital vein were collected into EDTA containing tubes before and 0.167, 0.333, 0.500, 0.750, 1.00, 1.25, 1.50, 1.75, 2.00, 2.50, 3.00, 4.00, 6.00, $8.00,12.0,16.0,24.0,36.0,48.0,72.0$ hours after administration of each Clopidogrel $75 \mathrm{mg}$ tablet.

\section{Drug analysis}

Blood samples were cooled in an bath and centrifuged at 3.000 rpm for at least $10 \mathrm{~min}$ at approximately $4^{\circ} \mathrm{C}$. At least $3 \mathrm{~mL}$ of plasma were dispensed into polypropylene tubes. Sample tubes were frozen at $-20^{\circ} \mathrm{C}$, and maintained to that temperature until analysis. All samples from a single volunteer were analyzed on the same day in order to avoid interassay variation.

Plasma concentrations of carboxylic acid of Clopidogrel, the major metabolite of Clopidogrel, were determined by the HPLC coupled with tandem mass spectrometry (LC/MS/MS), using enalapril maleate as internal standard (IS). This apparatus consisted of a Shimadzu LC-10ADvp pump, and Micromass QuattroLC triple-quadrupole mass spectrometer. The analytes were extracted automatically from plasma using a SPE system consisted of a Prospekt-2 ${ }^{\mathrm{TM}}$ on line solid phase extraction apparatus, using Oasis HLB Prospekt's cartridges. The validated method show a Lower limit of quantification of $10 \mathrm{ng} / \mathrm{mL}$ and linearity $>0,98$.

The analytical column was a Chromolith-RP18, $100 \times$ x 4, 6 $\mathrm{mm}, 5 \mu$ (Merck). The mobile phase used was a mixture of acetonitrile and water $(50: 50 \mathrm{v} / \mathrm{v})$, containing $20 \mathrm{mM}$ acetic acid. The chromatographic run time lasted 3.0 minutes with flow rate of $1.0 \mathrm{~mL} / \mathrm{min}$, in ambient temperature.

\section{Pharmacokinetic analysis and statistical analysis}

The first-order terminal elimination rate constant $(\mathrm{Ke})$ was estimated by linear regression from the points describing the elimination phase on a log-linear plot, using the software $S A S \AA$ Institute (Version 9.1.3). Elimination half-life $\left(\mathrm{T}_{1 / 2}\right)$ was derived from this rate constant $\left(T_{1 / 2}=\ln (2) / \mathrm{Ke}\right)$. The maximum observed plasma concentration $\left(\mathrm{C}_{\max }^{1 / 2}\right)$ and the time taken to achieve this concentration $\left(\mathrm{T}_{\max }\right)$ were obtained directly from the curves. The areas under the clopidogrel metabolite plasma concentration versus time curves from 0 to 72 hours $\left(\mathrm{AUC}_{0-72 \mathrm{~h}}\right)$ were calculated by applying the linear trapezoidal rule. Extrapolation of these areas to infinity $\left(\mathrm{AUC}_{0-\infty}\right)$ was done by adding the value $\mathrm{C} 72 / \mathrm{Ke}$ to the calculated $\mathrm{AUC}_{0-72 \mathrm{~h}}$ (where $\mathrm{C} 72=$ plasma concentration calculated from the log-linear regression equation obtained for the estimation of Ke 72 hours after dose).

The bioequivalence between both formulations was assessed by calculating individual $\mathrm{C}_{\max }, \mathrm{AUC}_{0-72 \mathrm{~h}}, \mathrm{AUC}_{0-\infty}$ and $\mathrm{C}_{\max } / \mathrm{AUC}_{0-}$ 72h ratios (test/reference) together with their mean and $90 \%$ confidence intervals (CI) after log transformation of the data. The inclusion of the $90 \% \mathrm{CI}$ for the ratio in the $80 \%$ to $125 \%$ range was analyzed by nonparametric (SAS® Institute Version 9.1.3) and parametric (ANOVA) methods.

\section{Results}

\section{Tolerability analysis}

Clopidogrel was well tolerated at the administered dose. All the biochemical parameters did not any clinical relevant alterations. No adverse effects were either reported or observed.

\section{Pharmacokinetic and statistical analysis}

The mean $( \pm$ SD) plasma concentration time profile of the 2 formulations, shown in Figure 1, was similar and superimposable.

Central and dispersion measures for all pharmacokinetic parameters for both formulations are shown in Table 1 and Table 2. From this, the mean values of $\mathrm{C}_{\max }$ were found to be 4392.14 $( \pm 1753.75$ standard deviations $[\mathrm{SD}]) \mathrm{ng} / \mathrm{mL}$ for the reference product and $4469.52( \pm 1190.44) \mathrm{ng} / \mathrm{mL}$ for the locally manufactured (test) product. For $\mathrm{T}_{\max }(\mathrm{h})$, the mean values were found to be similar for both the reference and local product and the value was $1.0(2.0) \mathrm{h}$. The mean values of AUC0-72 were found to be $14433.14( \pm 3746.40) \mathrm{ng} . \mathrm{h} / \mathrm{mL}$ for reference and

J Bioequiv Availab
Volume 2(2): 045-049 (2010) - 046 


\section{Journal of Bioequivalence \& Bioavailability - Open Access \\ JBB/Vol.2 Issue 2}

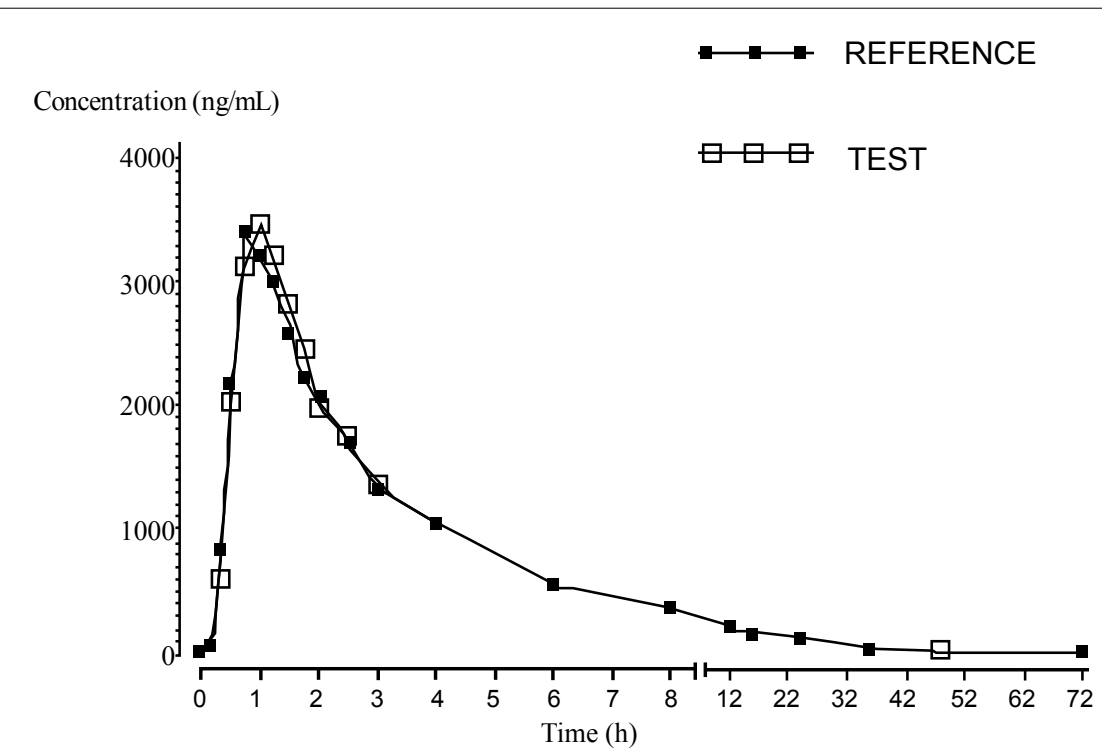

Figure 1: Clopidogrel plasma means concentration versus time profile obtained after the single oral acministration of $75 \mathrm{mg}$ of carvedilol formulation.

\begin{tabular}{|l|l|l|l|l|}
\hline & \multicolumn{2}{|c|}{ TEST } & \multicolumn{2}{|c|}{ REFERENCE } \\
\hline Paraneter (unit) & $\begin{array}{l}\text { Mens } \\
\text { (Median) }\end{array}$ & $\begin{array}{l}\text { Standard } \\
\text { Deviation } \\
\text { (Amplitude) }\end{array}$ & $\begin{array}{l}\text { Mens } \\
\text { (Median) }\end{array}$ & $\begin{array}{l}\text { Standard } \\
\text { Deviation } \\
\text { (Amplitude) }\end{array}$ \\
\hline $\mathrm{AUC}_{0-1}(\mathrm{ng}, \mathrm{h} / \mathrm{mL})$ & 14466.86 & 3714.07 & 14433.14 & 3746.40 \\
\hline $\mathrm{AUC}_{0 \text {-inf }}(\mathrm{ng}, \mathrm{h} / \mathrm{mL})$ & 14834.12 & 3734.70 & 14989.82 & 3687.03 \\
\hline $\mathrm{C}_{\max }(\mathrm{ng}, \mathrm{h} / \mathrm{mL})$ & 4469.52 & 1190.44 & 4392.14 & 1753.75 \\
\hline $\mathrm{T}_{\max }(\mathrm{median} / \mathrm{amp})(\mathrm{h})$ & 1.00 & 2.00 & 1.00 & 2.00 \\
\hline $\mathrm{Kel}(1 / \mathrm{h})$ & 0.07 & 0.02 & 0.07 & 0.02 \\
\hline $\mathrm{T} 1 / 2($ median/amp) $(\mathrm{h})$ & 9.50 & 13.01 & 9.58 & 18.68 \\
\hline
\end{tabular}

Table 1: Mean pharmacokinetic parameters of clopidogrel cardoxlic acid of test and reference formulation.

\begin{tabular}{|c|c|c|}
\hline & TEST & REFERENCE \\
\hline Parameter (unit) & Geometric Mean & Geometric Mean \\
\hline $\mathrm{AUC}_{0-1}(\mathrm{ng}, \mathrm{h} / \mathrm{mL})$ & 14016.94 & 13971.36 \\
\hline $\mathrm{AUC}_{0-\mathrm{inf}}(\mathrm{ng}, \mathrm{h} / \mathrm{mL})$ & 14395.78 & 14546.87 \\
\hline $\mathrm{C}_{\max }(\mathrm{ng}, \mathrm{h} / \mathrm{mL})$ & 4322.35 & 4084.09 \\
\hline
\end{tabular}

Table 2: Geometric mean pharmacokinetic parameters of clopidogrel carboxylic acid of test and reference formulation.

\begin{tabular}{|l|l|l|l|l|l|}
\hline Parameter & Ratio T/R (\%) & Lower Limit (\%) & Upper Limit (\%) & Power (\%) & $\begin{array}{l}\text { Coefficient of } \\
\text { variation (\%) }\end{array}$ \\
\hline \multicolumn{1}{|c|}{ AUC $_{0-1}$} & 100.33 & 95.50 & 105.40 & 99.99 & 13.31 \\
\hline $\mathrm{AUC}_{0 \text {-inf }}$ & 98.96 & 94.45 & 103.69 & 99.99 & 12.60 \\
\hline $\mathrm{C}_{\max }(\mathrm{m}$ (\%) $(\mathrm{h})$ & 105.83 & 95.91 & 116.78 & 87.49 & 26.91 \\
\hline $\mathrm{T}_{\max }$ & 0.00 & -0.25 & 0.25 & & \\
\hline
\end{tabular}

Table 3: Ratios means and the $90 \%$ geometric confidence interval of test and reference formulation.

$14466.86( \pm 3714.07) \mathrm{ng} . \mathrm{h} / \mathrm{mL}$ for local product. The mean AUC $_{0-\infty}$ were found to be $14989.82( \pm 3687.03) \mathrm{ng} \cdot \mathrm{h} / \mathrm{mL}$ and $14834.12( \pm 3734.70) \mathrm{ng} . \mathrm{h} / \mathrm{mL}$ for the reference and locally manufactured product, respectively.

Table 3 presents the ratios and the respective confidence intervals for bioequivalence analysis.

\section{Discussion}

Clopidogrel is an analogous molecule to ticlopidine and quickly binds to the platelet inhibition platelet aggregation (Bernat et al., 1993). Clopidogrel is metabolized by the liver originating its major inactive metabolite, the carboxylic acid. Due its extensive metabolization methods were developed for the quantifications in plasma of carboxylic acid.

The quantification of various drugs by chromatography with tandem mass spectrometry is if becoming each more common time due to improvement in the sensitivity and the selectivity of this method(Takahashi et al., 2008; Bahrami et al., 2008; Ksycinska et al., 2006; Nirogi et al., 2006; Mitakos and Panderi, 2004; Shin and Yoo, 2007; Sippel et al., 2008). With the advance of the chromatography the quality in the determination of the concentrations is more precise, getting a lower LOQ and better analysis of results.

A few analytical methods have been published for determination of the inactive metabolite of clopidogrel in the biological matrix. A sensitive gas chromatography-mass spectrometric method with LOQ of $0.005 \mu \mathrm{g} / \mathrm{mL}$ has been published (Lagorce et al., 1998). In this technique however, a complex two steps extraction method using both liquid-liquid and solid phase extraction procedures as well as derivatization of the analyte are required. Two LC-MS methods for the determination inactive metabolite of clopidogrel have been Volume 2(2): 045-049 (2010) - 047 
Citation: Abib E, Duarte LF, Vanunci MLP, Oliveira de DA, Antonelli S, et al. (2010) Comparative Biological Availability of Clopidogrel Formulation in Healthy Volunteers After a Single Dose Administration. J Bioequiv Availab 2: 045-049. doi:10.4172/ jbb. 1000029

published (Mitakos and Panderi, 2004; Ksycinska et al., 2006). In the method described by (Mitakos and Panderi, 2004) extraction of the analyte from the serum has been achieved using single step solid phase extraction however, their method is not sensitive enough (LOQ $0.1 \mu \mathrm{g} / \mathrm{mL}$ ) to be used in single-dose pharmacokinetic studies of the drug. In the other published LC-MS method (Ksycinska et al., 2006) two steps timeconsuming extraction procedure using both liquid-liquid and solid phase extraction techniques have been used however, the method is sensitive enough (LOQ 0.02 $\mu \mathrm{g} / \mathrm{mL}$ ) for measuring of the analyte up to at least three half lives post-dose. The inactive metabolite of the drug has been measured in Wistar rat plasma using HPLC and UV detection (Singh et al., 2005). In this method however, LOQ of $0.125 \mu \mathrm{g} /$ $\mathrm{mL}$ has been reported using $50 \mu \mathrm{L}$ injection. Furthermore, this method involves long run time of analysis (16 min) and gradient elution of the mobile phase. In HPLC-UV technique described by (Souri et al., 2006) ticlopidine has been used as internal standard. To overcome close retention times of clopidogrel carboxylic acid and ticlopidine, they used a mobile phase with low flow rate $(0.9 \mathrm{~mL} / \mathrm{min})$ and high percent of aqueous phase which leads to long analytical run time (12 $\mathrm{min})$ and reduction of sensitivity (LOQ $0.2 \mu \mathrm{g} / \mathrm{mL}$ ). To improve run time and sensitivity of the analysis, the flow rate should be increased and it is preferred to select a mobile phase with higher proportion of organic solvent. Thus, comparing to their method (Souri et al., 2006), we used a mobile phase with higher flow rate and more proportion of the organic solvent. Determination of clopidogrel in human plasma by liquid chromatography/tandem mass spectrometryhas been reported (Shin and Yoo, 2007). As lowblood levels of the intact drug is achieved following single dose administration (Planes et al., 1999; Beom et al., 2007) and considering difference in polarity between the drug and its inactive metabolite, like other published papers (Lagorce et al., 1998; Souri et al., 2006), our method failed to detect peak of clopidogrel in the samples. However, the major advantages of the present method are reduction in run time of analysis (3.0 min) and improvement of sensitivity (LOQ $10 \mathrm{ng} / \mathrm{mL}$ ) which allows determination of the analyte up to three half-lives postdose more precisely, so that the extent of absorption until the last sampling time is more closer to its extrapolated value ( $\left.\mathrm{AUC}_{0-\infty}\right)$.

The bioavailability of a pharmaceutical form refers to the extent and speed of absorption of the active principle in contained it. Two pharmaceutical forms are said bioequivalent when, to be administered to the same individual, in the same experimental conditions and at the same dose, showed no significant differences in relation to bioavailability. In this study two formulations of Clopidogrel had been evaluated. The mean ratio of parameters $\mathrm{C}_{\max }$ and $\mathrm{AUC}_{0-\mathrm{t}}$ and $90 \%$ confidence intervals of correspondents were calculated to determine the bioequivalence. The means $\mathrm{AUC}_{0-\mathrm{t}}$ for test and reference formulation were $14466.86 \mathrm{ng} . \mathrm{h} / \mathrm{mL}$ and $14433.14 \mathrm{ng} . \mathrm{h} / \mathrm{mL}$, for $\mathrm{AUC}_{0 \text {-inf were }}$ $14834.12 \mathrm{ng} . \mathrm{h} / \mathrm{mL}$ and $14989.82 \mathrm{ng} . \mathrm{h} / \mathrm{mL}$ and, for $\mathrm{C}_{\max } 4469.52$ $\mathrm{ng} / \mathrm{mL}$ and $4392.14 \mathrm{ng} / \mathrm{mL}$, respectively. The ratios were $100.33 \%$ for $\mathrm{AUC}_{0-\mathrm{t}}, 98.96 \%$ for $\mathrm{AUC}_{0-\text { inf }}$ and $105.83 \%$ for $\mathrm{C}_{\max }$. The $90 \%$ confidence intervals were $95.50-105.40 \%$ for $\mathrm{AUC}_{0-\mathrm{t}}$, 94.45- $03.69 \%$ for $\mathrm{AUC}_{0-\text { inf }}$ and $95.91-116.78 \%$ for $\mathrm{C}_{\max }$.

The $\mathrm{AUC}_{0-\mathrm{t}}$ and $\mathrm{AUC}_{0-\infty}$ are both recognized as an uncontaminated measurement of the extent of absorption. The J Bioequiv Availab present study showed that $90 \% \mathrm{CI}$ of mean $\mathrm{AUC}_{0-\mathrm{t}}$ and $\mathrm{AUC}_{0-\infty}$ (after log-transformation of individual ratios) were included into the bioequivalence range (80-125\%), consequently, the two formulations of clopidogrel are equivalent for the extend of absorption.

The statistical comparison of $\mathrm{C}_{\max }, \mathrm{AUC}_{0-\mathrm{t}}$ and $\mathrm{AUC}_{0-\infty}$ clearly indicated no significant difference in the two formulations of clopidogrel $75 \mathrm{mg}$ tablet. $90 \%$ confidence intervals for the mean ratio (T/R) of $\mathrm{C}_{\max }, \mathrm{AUC}_{0-\mathrm{t}}$ and $\mathrm{AUC}_{0-\infty}$ were entirely within the US Food and Drug Administration acceptance range. Based on the pharmacokinetic and statistical results of this study, we can conclude that clopidogrel $75 \mathrm{mg}$ tablet (Sandoz, Brazil) is bioequivalent to Plavix ${ }^{\circledR} 75 \mathrm{mg}$ tablet (Sanofi-Synthelabo, Brazil), and that then the test product can be considered interchangeable in medical practice.

\section{Acknowledgments}

This research work is financially supported by the Scentryphar Clinical Research, Brazil.

\section{References}

1. Aronow WS (2007) Antiplatelet therapy in the treatment of atherothrombotic disease: considering the evidence. Geriatrics 62: 12-24. » CrossRef » PubMed » Google Scholar

2. Bahrami G, Mohammadi B, Sisakhtnezhad S (2008) High-performance liquid chromatographic determination of inactive carboxylic acid metabolite of clopidogrel in human serum: Application to a bioequivalence study. J Chromatogr B 864: 168-172. »CrossRef » PubMed » Google Scholar

3. Herbert JM, Frehel D, Vallee E, Kieffer G, Gouy D, et al. (1993) Clopidogrel, a novel antithrombotic agent. Cardiovasc Drug Rev 11: 180-198. »CrossRef »PubMed » Google Scholar

4. Ksycinska H, Rudzki P, Bukowska-Kiliszek M (2006) Determination of clopidogrel metabolite in human plasma by LC-MS. J Pharm Biomed Anal 41: 533-539. » CrossRef » PubMed » Google Scholar

5. Lagorce P, Perez Y, Ortiz J, Necciari J, Bressolle F (1998) Assay method for the carboxylic acid metabolite of clopidogrel in human plasma by gas chromatography-mass spectrometry. J Chromatogr B Biomed Sci 720: 107-117. »CrossRef » PubMed » Google Scholar

6. Majerus PW, Tollefsen DM (2006) Blood coagulation and anticoagulant, thrombolytic, and antiplatelet drugs. The Pharmacological Basis of Therapeutics 11:1483. »CrossRef » PubMed » Google Scholar

7. Mitakos A, Panderi I (2004) Determination of the carboxylic acid metabolite of clopidogrel in human plasma by liquid chromatography-electrospray ionization mass spectrometry. Analytica Chimica Acta 505: 107-114. »CrossRef » PubMed » Google Scholar

8. Nirogi RV, Kandikere VN, Shukla M, Mudigonda K, Maurya S, et al. (2006) Quantification of clopidogrel in human plasma by sensitive liquid chromatography/tandem mass spectrometry. Rapid Commun Mass Spectrom 20: 16951700. »CrossRef » PubMed » Google Scholar

9. Planès A, Samama MM, Lensing AW, Büller HR, Barre J, et al. (1999) Prevention of deep venous thrombosis after hip replacement-comparison between the low molecular weight heparins tinzaparin and enoxaparin. Thromb Haemost 81: 22-25. »CrossRef » PubMed » Google Scholar

10. Shin BS, Yoo SD (2007) Determination of clopidogrel in human plasma by liquid chromatography/tandem mass spectrometry: application to a clinical pharmacokinetic study. Biomed Chromatogr 21: 883-889. »CrossRef » PubMed » Google Scholar

11. Singh SS, Sharma K, Barot D, Mohan PR, Lohray VB (2005) Estimation of carboxylic acid metabolite of clopidogrel in Wistar rat plasma by HPLC and its application to a pharmacokinetic study. J Chromatogr B Analyt Technol Biomed Life Sci 821: 173-180. »CrossRef » PubMed » Google Scholar

Volume 2(2): 045-049 (2010) - 048

ISSN:0975-0851 JBB, an open access journal 


\section{Journal of Bioequivalence \& Bioavailability - Open Access}

JBB/Vol.2 Issue 2

12. Sippel J, Sfair LL, Schapoval ES, Steppe M (2008) New high-performance liquid chromatographic method for determination of clopidogrel in coated tablets. J AOAC Intel 91: 67-72. »CrossRef » PubMed » Google Scholar

13. Souri E, Jalalizadeh H, Kebriaee-Zadeh A, Shekarchi M, Dalvandi A (2006) Validated HPLC method for determination of carboxylic acid metabolite of clopidogrel in human plasma and its application to a pharmacokinetic study. Biomed Chromatogr 20: 1309-1314. »CrossRef » PubMed » Google Scholar

14. Takahashi M, Pang H, Kawabata K, Farid NA, Kurihara A(2008) Quantitative determination of clopidogrel active metabolite in human plasma by LC-MS/ MS. J Pharm Biomed Anal 48: 1219-1224. »CrossRef » PubMed » Google Scholar 